УДК 656.212

\title{
ОПТИМІЗАЦІЯ РОБОТИ З ПОРОЖНІМИ ВАГОНАМИ НА ЗАЛІЗНИЦІ ІЗ ЗАСТОСУВАННЯМ ТЕОРІЇ УПРАВЛІННЯ ЗАПАСАМИ
}

\author{
К-т техн. наук П.В. Долгополов, магістрант О.С. Колмаков \\ ОПТИМИЗАЦИЯ РАБОТЫ С ПОРОЖНИМИ ВАГОНАМИ \\ НА ЖЕЛЕЗНОЙ ДОРОГЕ С ПРИМЕНЕНИЕМ \\ ТЕОРИИ УПРАВЛЕНИЯ ЗАПАСАМИ
}

\section{К-т техн. наук П.В. Долгополов, магистрант А.С. Колмаков \\ OPTIMIZATION OF EMPTY WAGONS WORK ON THE RAILWAY WITH USING INVENTORY MANAGEMENT THEORY}

\section{Cand. of tech. science P.V. Dolgopolov, master student A.S. Kolmakov}

Розроблено заходи з оптимізації оперативного резервування порожніх вагонів на вантажних та сортувальних станціях на основі математичного апарату теорії управління запасами. Застосування розробленої моделі дозволить в оперативному режимі формувати оптимальний резерв вагонів в умовах обмеженості справного рухомого складу $і$ скоротити витрати від зривів доставки вантажу клієнтам залізниці.

Ключові слова: Оперативний резерв, порожні вагони, вантажна станція, теорія управління запасами, резерв вагонів, інтелектуальні системи оперативного управління, система з фіксованим інтервалом часу між замовленнями.

Разработаны меры по оптимизации оперативного резервирования порожних вагонов на грузовых и сортировочных станциях на основе математического аппарата теории управления запасами. Применение разработанной модели позволит в оперативном режиме формировать оптимальний резерв вагонов в условиях ограниченности исправного подвижного состава и сократить расходы от срывов доставки груза клиентам.

Ключевые слова: Оперативный резерв, порожние вагоны, грузовая станция, теория управления запасами, резерв вагонов, интеллектуальные системы оперативного управления, система с фиксированным интервалом времени между заказами.

At the article are proposed the measures designed to optimize the operative reserves of empty wagons on freight stations and marshalling yards on the basis of mathematical apparatus of the the theory of inventory management The application of the developed model will allow on-line to form the optimum reserve of wagons under conditions shortage of serviceable rolling stock and reduce costs by disruption of freight delivery to clients.

Implementation of the proposed technology is advantageously carried out on the basis of intelligent online control systems. On the example of the one freight station determined that it is advantageous to maintain a reserve of wagons according to system of inventory management with fixed time interval between orders. 
Keywords: The operative reserves, empty wagons, freight station, theory of inventory management, reserve of wagons, intelligent online control systems, system with fixed time interval between orders.

Вступ і актуальність теми. В умовах посилення конкуренції на ринку транспортних послуг для залізничного транспорту, операторських компаній та промислових підприємств однією з головних задач є стабільність процесу обслуговування вантажовласників [1,2,3]. Цьому сприяє створення резервів рухомого складу, що вимагає значних капіталовкладень.

Якщо керівництво будь-якого підприємства налаштоване оптимістично щодо перспектив економічного зростання, то приймається рішення зі збільшення обсягу інвестицій у створення резервів вагонного парку. Проте, 3 точки зору ресурсозбереження, такий підхід не $\epsilon$ зваженим - і особливо під час нестабільної економічної ситуації у країні, як зараз.

Виходячи 3 цього, на даний час актуальною постає задача оптимізації планування оперативного резерву порожніх вагонів на вантажних та сортувальних станціях на основі математичних методів. Реалізацію запропонованої технології доцільно проводити із застосуванням інтелектуальних систем оперативного управління.

Постановка задачі. Таким чином, метою даної наукової роботи $\epsilon$ розробка математичної моделі оптимізації резерву порожніх вагонів на станціях навантаження на основі математичного апарату теорії управління запасами. Застосування даної моделі дозволить в оперативному режимі формувати оптимальний резерв в умовах обмеженості справного рухомого складу i скоротити витрати від зривів доставки вантажу замовникам.

В логістиці товарно-матеріальні запаси вважаються фактором, що забезпечує безпеку системи матеріально-технічного постачання, іii гнучке функціонування, i постають в якості «страховки» $[3,4,5]$.

Визначення точної величини резерву вагонного парку на станціях, необхідного в умовах нестабільності термінів реалізації замовлень i мінливого попиту на вагони різного роду ускладнено ймовірнісною природою даних коливань. Це вказує на те, що для отримання задовільних рішень задач, пов'язаних 3 визначенням резерву вагонів, доцільно застосовувати математичні апарати імітаційного моделювання.

На основі аналізу існуючих математичних методів зроблено висновок про доцільність застосування при дослідженнях математичного апарату теорії управління запасами.

Основний зміст досліджень. Під час наукових досліджень проаналізовано існуючу систему регулювання парку порожніх вагонів та зроблено висновок, що в умовах домінування вагонного парку власності компаній-операторів $є$ необхідним подальший розвиток та застосування ймовірнісного планування резерву порожніх вагонів не на декаду, а на більш короткі терміни. При плануванні на декаду, майже завжди мають місце фактори, що не охоплені плануванням.

Згідно теорії управління запасами сформуємо основні стратегії та проаналізуємо можливість їх застосування відповідно мети безупинного забезпечення вантажовласника навантажувальними ресурсами:

- стратегія управління резервом вагонного парку з фіксованим розміром замовлення;

- стратегія 3 фіксованим інтервалом часу між замовленнями;

- стратегія зі встановленою періодичністю поповнення резерву до постійного рівня;

- стратегія «мінімум-максимум».

Система безупинного забезпечення потреби металургійного та енергетичного виробництва, яке домінує на базовому полігоні, повинна враховувати можливість появи різних відхилень у постачанні як з боку споживача резерву, так і з боку виконавця замовлення. Тому, для вирішення задачі оптимізації управління запасами необхідно побудувати модель стохастичного програмування [5,6]. 
У зазначених стратегіях керування резервами вагонів, незважаючи на орієнтацію ï на стабільні умови функціонування, передбачена можливість згладжування збоїв у постачаннях і споживанні. Так, стратегія 3 фіксованим розміром замовлення враховує один з восьми впливів, що збурюють (рис. 1), а саме затримку постачання. Цей вплив знімається введенням у систему параметра гарантійної величини резерву (ГВР), яка визначає рівень, при якому знову замовляються вагони. ГВР розраховується таким чином, що надходження замовлення відбувається в момент зниження поточного резерву до гарантійного рівня.

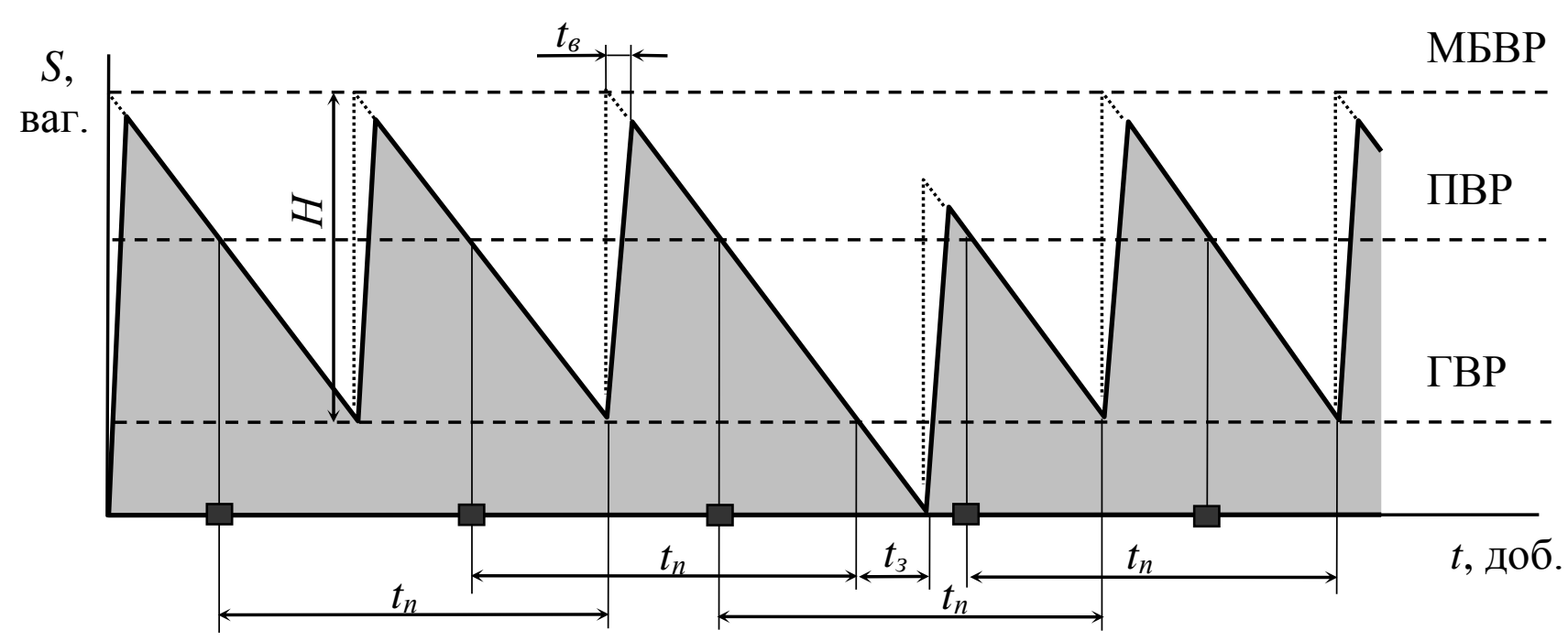

Рис. 1. Застосування стратегії управління порожніми вагонами з фіксованим розміром замовлення

Розмір замовлення вагонів строго зафіксований i не міняється в умовах роботи. Основною задачею стратегії $\epsilon$ визначення розміру замовлення.

Гарантійний (страховий) запас дозволяє забезпечувати потребу на час передбачуваної максимально можливої затримки постачання вагонів.

Максимальниа бажана величина резерву (МБВР) визначається для відстеження доцільного завантаження колій 3 погляду критерію мінімізації сукупних витрат.

Якщо можлива затримка постачання буде являти собою максимально можливу затримку, то механізм системи охоронить споживача від дефіциту у випадку одиничного збою в постачаннях. Другий розрахунковий параметр системи граничний рівень забезпечує підтримку системи в бездефіцитному стані. Період же часу, через який поповнюють гарантійний запасу до розрахункового обсягу, залежить від конкретних значень вихідних i фактичних параметрів системи.

Стратегія $з$ фіксованим інтервалом часу між замовленнями також враховує вплив затримки, що поставки, постачання (рис. 2). Оптимальний розмір замовлення при цьому дозволяє мінімізувати сукупні витрати на збереження резерву i повторення замовлення, а також досягти найкращого сполучення взаємодіючих факторів, таких, як використовувана довжина колій, витрати на збереження резервів i вартість замовлення.

ГВР дозволяє забезпечувати потребу на час передбачуваної затримки постачання. Заповнення гарантійного резерву виробляється в ході наступних постачань через перерахування розміру замовлення так, щоб його постачання збільшило резерв до максимального бажаного рівня [3].

Як i в системі 3 фіксованим розміром замовлення, цей вплив знімається параметром гарантійного запасу. Заповнення гарантійного запасу до розрахункового обсягу виробляється під час 
наступних постачань через перерахування розміру замовлення таким чином, щоб його постачання

збільшило резерв максимального бажаного рівня.

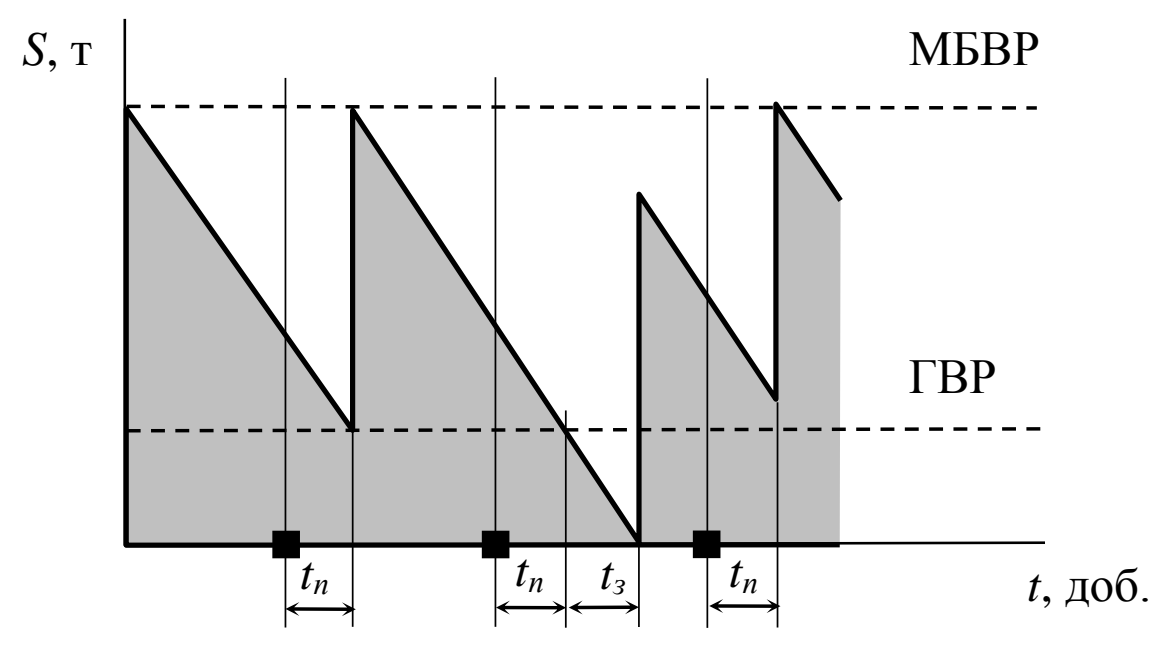

Рис. 2. Стратегія з фіксованим інтервалом часу між замовленнями вагонів

Стратегія 3 установленою періодичністю поповнення запасів до постійного рівня, на відміну від основних систем керування запасами, враховує можливість як затримки постачання, так i зміни темпів споживання від запланованих. Розширення здатності системи протистояти незапланованим впливам, що обурюють, зв'язано з об'єднанням ідей використання граничного рівня і фіксованого інтервалу між замовленнями. Відстеження граничного рівня підвищує чутливість системи до можливих коливань інтенсивності споживання.

Стратегія «мінімум-максимум» орієнтована на ситуацію, коли витрати на облік резервів на коліях і витрати на оформлення замовлення настільки значні, що стають порівнянні з утратами від дефіциту резервів. Це єдина 3 розглянутих раніше систем, що допускає дефіцит резервів по економічних розуміннях. Проте i система «мінімуммаксимум» враховує можливість затримки постачання через параметр гарантійного запасу.

Порівняння розглянутих стратегій управління резервом управління резервами приводить до виводу про наявність у них взаємних недоліків i переваг. Так, стратегія 3 фіксованим розміром замовлення вимагає безупинного обліку поточного резерву на складі. Навпроти, стратегія 3 фіксованим інтервалом часу між замовленнями вимагає лише періодичного контролю кількості резерву. Необхідність постійного обліку резерву в системі 3 фіксованим розміром замовлення можна розглядати як основний iii недолік. Відсутність постійного контролю за поточним резервом у системі 3 фіксованим інтервалом часу між замовленнями $\epsilon$ iï основною перевагою перед першою системою $[7,8]$.

У стратегії з фіксованим розміром замовлення МБВР завжди має менший розмір. Це приводить до економії на витратах по змісту резервів за рахунок скорочення колій, займаних резервами, що, у свою чергу, складає перевагу системи 3 фіксованим розміром замовлення перед стратегією з фіксованим інтервалом часу між замовленнями.

Оптимальний розмір партії $H_{\text {onm }}$ вагонів та їх завезення до вугільних шахт залежать від наступних факторів:

- обсяг оберту вагонів;

- транспортно-заготовчі витрати;

- витрати на простій резерву.

Досліджено, що при збільшенні розміру замовлення вагонів $H$ транспортно- 
підготовчі витрати зменшуються, оскільки перевезення здійснюється більш значними партіями, та, відповідно, рідше. Однак, витрати на зберігання вагонів $C_{x p}$ від $H$ мають прямо пропорційну залежність.

Задача визначення оптимального розміру замовлення може бути розв'язана графічним способом, причому, сумарні витрати на транспортування та зберігання становлять

$$
C=C_{m 3}+C_{x p} .
$$

Для розв'язання задачі визначення оптимального розміру замовлення аналітичним шляхом необхідно мінімізувати цільову функцію

$$
C=C_{x p}+C_{m 3} \rightarrow \min .
$$

Нехай за певний період $T$ часу оберт вагонів становить $Q_{T}$, а розмір однієї партії $H$.

Важливим елементом аналітичного розв'язання задачі $\epsilon$ розмір тарифу $c_{x p}$ за простій вагонів на коліях, що являє собою долю, яку складають витрати на зберігання за період $T$ у вартості середнього резерву за даний період.

Тоді, витрати на зберігання дорівнюють

$$
C_{x p}=\frac{c_{x p} \cdot H}{2}
$$

Розмір транспортно-приготовчих витрат становить $[5,6,9]$

$$
C_{m 3}=\frac{c_{m 3} \cdot Q_{T}}{H},
$$

де $c_{m з}$ - транспортно-заготовчі витрати, що пов'язано 3 розміщенням та доставкою одного заказу, грн.

Тоді, згідно (1-4), маємо

$$
\begin{aligned}
& C=\frac{c_{x p} \cdot H}{2}+\frac{c_{m 3} \cdot Q_{T}}{H} . \\
& H_{\text {onm }}=\sqrt{\frac{2 \cdot c_{m 3} \cdot Q_{T}}{c_{x p}}} .
\end{aligned}
$$

Перевірка показує, що $C^{\prime}>0$, тобто, отримане значення $H_{\text {onm }}$ забезпечує мінімум сумарних витрат на доставку та зберігання.
Значення та $c_{x p}$ здійснено на основі статистичних даних про транспортнозаготовчі витрати.

Кошторис витрат $c_{m з}$ включає наступні складові:

$x_{1}$ - витрати, що вов'язано 3 організацією замовлення, грн.;

$x_{2}$ - витрати на транспортування вантажу, грн.;

$x_{3}$ - інші витрати, що пов'язано 3 виконанням заказу, грн.

Тоді, враховуючи дані складові, маємо

$$
c_{m 3}=\frac{\sum_{i=1}^{n} x_{i}}{N_{3}},
$$

де $N_{3}$ - кількість заказів, що здійснено за період $T$.

Витрати $c_{x p}$ включають наступні складові:

$y_{1}$ - витрати на амортизацію колій, грн;

$y_{2}$ - витрати на можливий кредит для придбання резерву вагонів, грн;

$y_{3}$ - витрати на заробітну плату персоналу, пов'язаного технічним обслуговуванням резервів, грн.;

$y_{4}$ - адміністративні витрат, грн;

$y_{5}$ - витрати на охорону, втрати через пошкодження, грн. та інші $[6,10]$.

Отже,

$$
c_{x p}=\frac{2 \cdot \sum_{i=1}^{n} y_{i}}{H} .
$$

На основі моделювання та зібраних статистичних даних про місцеву роботу базової вантажної станції Д на рис. 3 отримано залежність $H=f\left(Q_{T}\right)$, за допомогою якої доцільно обрати оптимальний розмір замовлення порожніх вагонів в залежності від середньодобової величини навантаження.

Розрахунок параметрів систем управління запасами наведено у таблиці 1.

Величина резерву вагонів, яка повинна підтримуватися, на коліях в середньому за період спостережень при впровадженні системи з фіксованим розміром замовлення, становить 


$$
S_{c p}^{H}=\frac{H \cdot\left(t_{M \overline{0}-n}+t_{n}\right) \cdot\left(1-P_{3}\right)+\left(H-S_{2}\right) \cdot\left(t_{n}+t_{M \overline{0}-n}-t_{3}\right) \cdot P_{3}-t_{3} \cdot S_{2} \cdot P_{3}}{4}+S_{2}-\frac{t_{3} \cdot S_{2} \cdot P_{3}}{4} .
$$

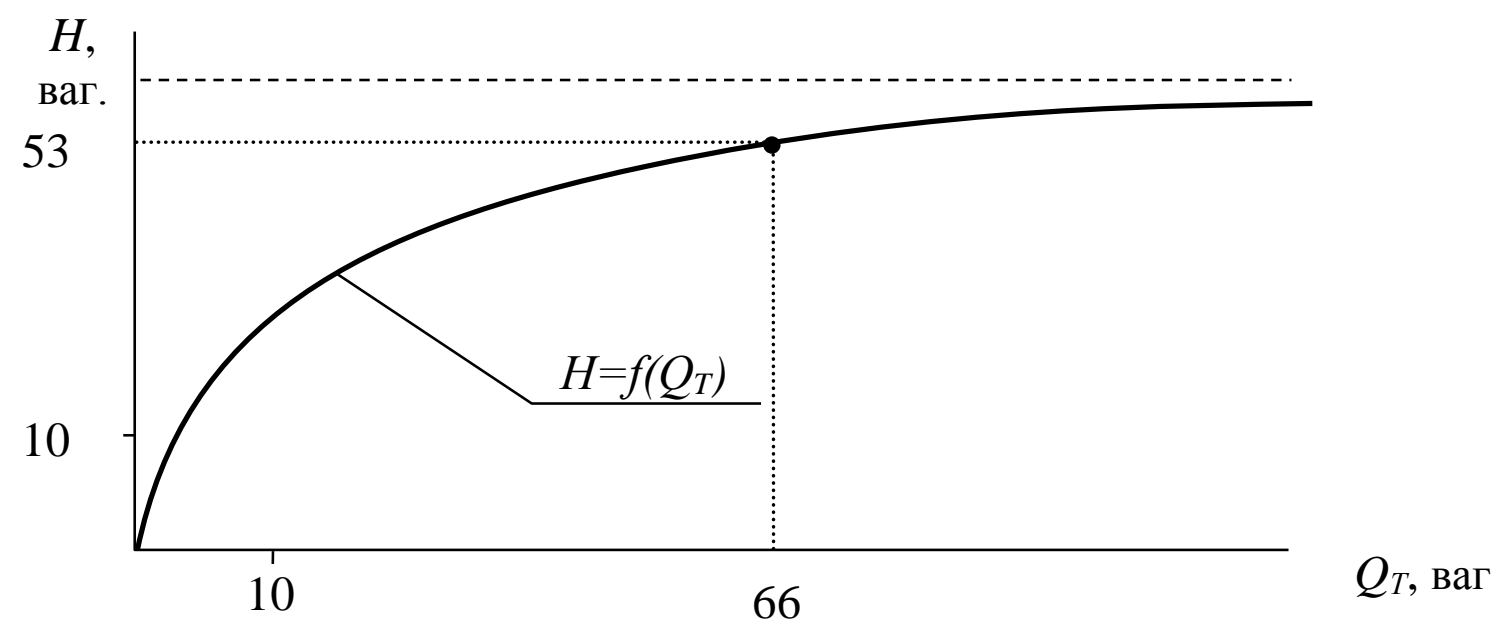

Рис. 3. Залежність оптимального розміру замовлення порожніх вагонів від їх обігу для базової вантажної станції Д

Таблиця 1

Визначення параметрів стратегій управління резервами вагонів

\begin{tabular}{|l|c|c|}
\hline \multicolumn{1}{|c|}{ Параметр } & \multicolumn{1}{|c|}{$\begin{array}{c}\text { Порядок } \\
\text { визначення }\end{array}$} & $\begin{array}{c}\text { Розрахунок } \\
\text { та результат }\end{array}$ \\
\hline Середньодобова потреба, ваг. & $Q_{T}$ & 66 \\
\hline $\begin{array}{l}\text { Оптимальний розмір замовлення, } \\
\text { ваг. }\end{array}$ & $H$ & 03 \\
\hline Тривалість поставки, доб. & $t_{n}$ & 0,81 \\
\hline Можлива затримка поставки, доб. & $t_{3}$ & $0,81 \cdot 66=54$ \\
\hline $\begin{array}{l}\text { Очікувана потреба за час поставки, } \\
\text { ваг. }\end{array}$ & $q_{n}=t_{n} \cdot Q_{T}$ & $66 \cdot(0,81+0,23)=69$ \\
\hline $\begin{array}{l}\text { Максимальна потреба за час } \\
\text { поставки, ваг. }\end{array}$ & $q_{n}{ }^{m a x}=Q_{T} \cdot\left(t_{n}+t_{3}\right)$ & $69-54=15$ \\
\hline ПВР, ваг. & $S_{n}=q_{n}{ }^{m a x}-q_{n}$ & $15+54-66=3$ \\
\hline \begin{tabular}{l} 
ГВР, ваг. \\
\hline МБВР, ваг.
\end{tabular} & $S_{2}=S_{n}+q_{n}-Q_{T}$ & $3+53=56$ \\
\hline Час вживання резерву до ПВР, доб. & $t_{m \sigma-n}=\left(S_{m \sigma}-S_{2}+H\right.$ & $(56-15) / 66=0,62$ \\
\hline $\begin{array}{l}\text { Час вживання резерву з ПВР до } \\
\text { ГВР, доб. }\end{array}$ & $t_{n-2}=\left(S_{n}-S_{2}\right) / Q_{T}$ & $(15-3) / 66=0,18$ \\
\hline
\end{tabular}

Величина резерву вагонів, яка повинна підтримуватися, на коліях в середньому за період спостережень при впровадженні системи 3 фіксованим інтервалом часу між замовленнями, становить 


$$
S_{c p}^{t}=\frac{H \cdot I \cdot\left(1-P_{3}\right)+\left(\left(H-S_{2}\right) \cdot\left(I-t_{3}\right)-S_{2} \cdot t_{3}\right) \cdot P_{3}}{4}+S_{2}-\frac{t_{3} \cdot S_{2} \cdot P_{3}}{4},
$$

де $I$ - інтервал часу між замовленнями, доб.

$$
\begin{gathered}
I=\frac{H}{Q_{T}} . \\
I=\frac{53}{66}=0,83 \text { доб. }
\end{gathered}
$$

Отже,

$$
S_{c p}^{t}=\frac{53 \cdot 0,8 \cdot(1-0,37)+((53-3) \cdot(0,8-0,23)-3 \cdot 0,23) \cdot 0,37}{4}+4-\frac{0,23 \cdot 4 \cdot 0,37}{4}=15 \text { ваг }
$$

Таким чином, результати досліджень свідчать, що при застосуванні системи 3 фіксованим інтервалом часу між замовленнями, розмір резерву скорочується на 6 вагонів, що складає 26\%. Тому, при організації процесу перевезень на залізничному полігоні резерв вагонів на базовій вантажній станції Д доцільно підтримувати згідно системи управління запасами 3 фіксованим інтервалом часу між замовленнями.

Висновки 3 дослідження i перспективи. У статті розроблено математичну модель визначення оптимального резерву вагонного парку. Її застосування дозволить в оперативному режимі визначати динамічні параметри резерву порожніх вагонів на станціях масового навантаження згідно найбільш раціональної стратегії. Це в свою чергу дозволить скоротити витрати на утримання резерву вагонного парку, а також витрати від штрафних санкцій через несвоєчасне подавання вагонів та доставку вантажу. Реалізацію запропонованої технології доцільно проводити із застосуванням інтелектуальних систем оперативного управління.

\section{Список використаних джерел}

1. Транспортна стратегія України на період до 2020 року. Схвалена розпорядженням Кабінету Міністрів України від 16 грудня 2009 р. №1555-р.: [Электрон.ресурс]. - Режим доступа: http://www.mintrans.gov.ua/uk/discussion/15621. html/ 10.12.2009.

2. Концепція державної програми реформування залізничного транспорту України [Текст] / Схвалено розпорядженням КМУ №651-р від 27.12.2006. - К.: Магістраль, №1 (1179) 10-16 січня 2007 р. - С. 6.

3. Інформаційні системи та технології при управлінні залізничними перевезеннями: навч. посіб. [Текст] / О.В. Лаврухін, П.В. Долгополов, В.В. Петрушов, О.М. Ходаківський. Х.: УкрДАЗТ, 2010.-122 с.

4. Ульяницкий Е.М., Филоненков А.И., Ломаш Д.А. Информационные системы взаимодействия видов транспорта [Текст]: учебное пособие для вузов ж.-д. транспорта / Е.М. Ульяницкий, А.И. Филоненков, Д.А. Ломаш - М.: Маршрут, 2005. - 264 с.

5. Гаджинский А.М. Логистика [Текст]: учебник / А.М. Гаджинский. - М.: Маркетинг, 1998. - 228c.

6. Смехов А.А. Основы транспортной логистики [Текст]: учебник / А.А. Смехов. - М.: Транспорт, 1995. - 197c.

7. Долгополов, П.В. Удосконалення технології регулювання порожніх вагонів та планування їх резерву на залізничному полігоні [Текст] / П.В. Долгополов, О.Г. Бужор, О.В. Волков, В.В. Шаповалов // Зб. наукових праць /УкрДАЗТ: Харків, 2013. - Вип. 135. - С. 4550 . 
8. Долгополов, П.В. Удосконалення експлуатації порожніх вагонів державних операторських компаній на основі логістичних принципів [Текст] / П.В. Долгополов, М.С. Водолажська, I.О. Єфімцева // Зб. наукових праць /УкрДАЗТ: Харків, 2012. - Вип. 133. - С. 30-35.

9. Системы автоматизации и информационные технологи управления перевозками на железных дорогах [Текст]: Учебник для вузов ж.-д. транспорта / В.А. Гапанович, А.А. Грачев [и др.]; под ред. В.И. Ковалева, А.Т. Осьминина, Г.М. Грошева. - М.: Маршрут, 2006. -544 с.

10. Управление експлуатационной работой и качеством перевозок на железнодорожном транспорте [Текст] : учебник для вузов / П.С. Грунтов, Ю.В. Дьяков, А.М. Макарочкин [и др.] ; под ред. П.С. Грунтова - М.: Транспорт, 1994. - 543c.

Рецензент д-р техн. наук, професор О.В.Лаврухін

Долгополов Петро Віталійович, к.т.н., дочент, Украӥнська державна академія залізничного транспорту, кафедра управління експлуатаційною роботою 095-090-37-47 pit2013@таil.ru

Колмаков Олександр Сергійович, черговий по станиії, Донецька залізниця, 050-777-82-02 , w_e_a_p_o_n@mail.ru

Dolgopolov Peter, PhD, docent, Office of management of operational work, Ukrainian Sate Academy of Railway Transport 095-090-37-47 pit2013@mail.ru

Kolmakov Alexander, station train manager, Donetskaya railway, 050-777-82-02,w_e_a_p_o_n@mail.ru 